International Journal of Oceans and Oceanography

ISSN 0973-2667 Volume 14, Number 1 (2020), pp. 77-99

(C) Research India Publications

https://dx.doi.org/10.37622/IJoO/14.1.2020.77-99

\title{
Seasonal and Interannual Variations of Sardine Catches along the Omani Coast
}

\author{
Saud M. Al Jufaili and Sergey A. Piontkovski* \\ Sultan Qaboos University, P.O.Box 34, Muscat 123, Sultanate of Oman \\ *Corresponding author.
}

\begin{abstract}
Sardines contributed $85 \%$ to the total small pelagic fish landings by Oman, in 2000-2018. Monthly data on sardine catches represented mainly by the Indian oil sardine (Sardinella longiceps Valenciennes, 1847) and 19 environmental variables were subjected to the Principal Component Analysis which enabled us to elucidate factors driving seasonal and interannual fluctuations of sardine catches over three main fishery provinces. An increase of the catch and an increase in magnitude of seasonal fluctuations of these catches have been the main trends of the past two decades pronounced in a 30year time series (1988-2018). The wind speed, sea surface temperature, geostrophic current velocity, number of cyclonic eddies, the El-Niño Southern Oscillation, Indian Ocean Dipole, and large pelagic species (predators on sardines) were the environmental variables which modulated interannual variations of sardine catches along the Omani shelf overlooking the western Arabian Sea.
\end{abstract}

\section{INTRODUCTION}

Landings of small pelagic fishes (sardines, anchovies and herring) contribute about $19 \%$ ( 15 million tons) to the world fishery production (FAO, 2016). The commercial importance of this group is high especially in the northern Indian Ocean, in which the Indian oil sardine (Sardinella longiceps Valenciennes, 1847) leads industrial and artisanal catches. Indian fisheries contributed about $80 \%$ to the global oil sardine catch, in 1950-2014 (Kripa et al., 2018). However, sardine catches are highly variable, on seasonal, interannual and decadal scales (Lluch-Belda et al., 1989, Schwartzlose, et al., 1999), resulting in economic losses.

Overfishing coupled with environmental variations (in the form of intensity of a 
coastal upwelling, rainfall, sea surface temperature, food availability, wind speed and basin scale or global scale oscillations driving geostrophic currents) have been identified as the factors affecting variations of sardine catches over various geographic regions (Kripa et al., 2015; Longhurst and Wooster, 1990; Peck et al., 2013; Schwartzlose, et al., 1999). With this respect, the Arabian Sea variability is unique because it encompasses all aforementioned processes. A multiple scale coupling of physical, chemical and biological processes result in huge spatio-temporal gradients of characterizing them parameters, such as atmospheric pressure gradients inducing powerful monsoonal winds, seasonal coastal upwellings and winter convective mixing of the upper layers of the sea. These processes generate intensive enrichment of upper layers with nutrients, with subsequent magnitudes of primary and secondary production in the western Arabian Sea ranked among the highest in the world tropical ocean (Qasim, 1977; Longhurst, 1998; Piontkovski and Banse, 2006).

The main fish families caught by fishers of Oman in 1950-2015, were contributed by the Clupeidae ( 32\%), mackerels (Scombridae, $\sim 19 \%$ ), emperors (Lethrinidae, $\sim 6 \%$ ), jacks (Carangidae, 5\%), and groupers (Serranidae, 4\%) (Khalfallah et al., 2016).

R.V. "Rastrelliger" surveys along the Omani shelf conducted in the Arabian Sea in 1989, 1990 and 1995, reported the small pelagic fish biomass of about 252,000 tones contributed mainly by Sardinella longiceps, and other small pelagics (Johannesson, 1995). Later on, five consecutive seasonal surveys conducted by R.V. "Al Mustaqila 1 " along the Omani shelf, in 2007-20008, reported a stock of 1.9 million tones indicating a huge increase in the biomass of sardines and other small pelagics (Gauthier et al., 2009).

The Omani sardine fishery is a market driven coastal traditional fishery targeted by beach sein, purse sein, and encircling gillnets. The major part of the fishing effort is distributed along $1712 \mathrm{~km}$ of the coast overlooking the western Arabian Sea, in which sardines contributed $85 \%$ to the total small pelagic fish landings during the past two decades (Fishery Statistics Book, 2018). Sardinella longiceps contributes about $95 \%$ to Omani sardine landings (Dorr III et al., 1990). Several studies have attempted to identify spatio-temporal patterns of these landings (Al-Jufaili et al., 2006; Al-Jufaili, 2007; Al-Jufaili and Al-Jahwari, 2011; Piontkovski et al., 2014). The current paper extends aforementioned efforts and addresses factors driving seasonal and interannual fluctuations of sardine catches over three main fishery vilayats (provinces) along the Omani coast, namely, Ash-Sharqiyah, Al-Wusta, and Dhofar, of which the western Arabian Sea catches were compiled.

\section{METHODS}

Monthly time series of the concentration of chlorophyll- $a$, dissolved nitrate, mixed layer depth, euphotic layer depth, outgoing long wave radiation and sea surface temperature were retrieved from the NASA/Giovanni database as part of the NASA's Goddard Earth Sciences Data and Information Services Center (https://giovanni.gsfc.nasa.gov/giovanni). 
Along with remotely sensed parameters, this database incorporates products assimilated from the NASA Ocean Biogeochemical Model (NOBM), which is a coupled three-dimensional model with 14 vertical layers, incorporating general circulation, biogeochemical, radiative components and assimilating monthly global products (Gregg, 2008). The model is driven by wind stress, shortwave radiation and sea surface temperature. The assimilation process has an algorithm of constant readjustment of the model, based on the chlorophyll data acquired by satellite sensors. It is assumed that oceanic radiation is driven by water scattering, absorption, dissolved organic matter, and optical properties of the phytoplankton groups. The estimates of sea surface nitrates are based on the algorithms linking the shipboard with remotely sensed data.

The NOBM resembles phytoplankton groups, nutrients, a single herbivore group, and detrital pools along with the major ocean carbon components (Gregg and Casey, 2007). The spatial resolution of the model is $0.67^{\circ} \times 1.25^{\circ}$. Monthly data on dissolved nitrate, mixed layer depth, euphotic layer depth, outgoing long wave radiation and concentration of diatoms were retrieved from this model.

The inshore, offshore and alongshore migrations are common features of sardine population behavior. With this regard, the offshore gradients of sea surface temperature were computed and used as one of the variables subjected to the Principal Component Analysis. In particular, the offshore sea surface temperature gradient between two adjacent regions has been computed. The coordinate box of the western region $\left(16-22^{\mathrm{O}} \mathrm{N} ; 54-60^{\mathrm{O}} \mathrm{E}\right)$ had encompassed the Omani shelf, while the eastern region was located one degree offshore.

Zonal and meridional components of wind speed were retrieved from the NCAR/NCEP reanalysis database (Kistler et al., 2001), in which the monthly averages of wind speed at $10 \mathrm{~m}$ above sea level were extracted for the Omani shelf region overlooking the western Arabian Sea. The meridional component has a positive value when the wind is blowing from south to north. A south wind has a positive meridional constituent, while a north wind has a negative one. In the case of zonal component, values are positive when the wind is blowing from west to east. Thus, a western wind has a positive zonal constituent while an eastern wind has a negative one.

Monthly time series characterizing the Indian Ocean Dipole and the El-Niňo Southern Oscillation (El-Niňo 3.4) were downloaded from the NOAA website maintained by the Working Group on Surface Pressure (Table 1).

Maps for sea surface height anomalies enabling calculation of the amount of cyclonic and anticyclonic mesoscale eddies were acquired from the Archiving, Validation and Interpretation of Satellite Oceanographic Data Center website (http://www.aviso.oceanobs.com) and the CCAR Global Near Real-Time SSH Anomaly/Ocean Color Data Viewer (http://argo.colorado.edu/ realtime/modis). In following the approach proposed by Chelton et al. (2011) and Arur et al. (2014), the outermost closed contour resembling a vortex with a minimum $5 \mathrm{~cm}$ amplitude, was identified as an eddy. Cyclonic eddies (with anticlockwise rotation) were 
characterized by negative sea surface height anomalies depressed in cores of eddies, while anti-cyclonic eddies (with clockwise rotation) have positive sea surface height anomalies elevated in cores, within the bounding contour.

Table 1. Environmental variables used for the Principal Component Analysis.

\begin{tabular}{|c|c|c|}
\hline Variable & Time range & Data source \\
\hline $\begin{array}{l}\text { Gradient of atmospheric pressure at the sea } \\
\text { surface, mb }\end{array}$ & $1948-2018$ & http://www.esrl.noaa.gov/psd/data \\
\hline $\begin{array}{l}\text { Photosynthetically active radiation, } \\
\text { Einstein } \mathrm{m}^{-2} \text { day }^{-1}\end{array}$ & $1997-2015$ & https://giovanni.gsfc.nasa.gov \\
\hline $\begin{array}{l}\text { Meridional component of the wind speed, } \\
\mathrm{m} \mathrm{s}^{-1}\end{array}$ & $1948-2018$ & http://www.esrl.noaa.gov/psd/data \\
\hline $\begin{array}{l}\text { Zonal component of the wind } \\
\text { speed, } \mathrm{m} \mathrm{s}^{-1}\end{array}$ & $1948-2018$ & http://www.esrl.noaa.gov/psd/data \\
\hline $\begin{array}{l}\text { Sea surface temperature gradient, } \\
{ }^{\circ} \mathrm{C} \mathrm{km}^{-1}\end{array}$ & $1948-2018$ & http://www.esrl.noaa.gov/psd/data \\
\hline Sea surface temperature, ${ }^{\circ} \mathrm{C}$ & $1948-2018$ & https://giovanni.gsfc.nasa.gov \\
\hline Euphotic depth, m & $1997-2015$ & https://giovanni.gsfc.nasa.gov \\
\hline Mixed layer depth, $\mathrm{m}$ & $1997-2015$ & https://giovanni.gsfc.nasa.gov \\
\hline $\begin{array}{l}\text { Meridional component of geostrophic } \\
\text { current velocity, } \mathrm{m} \mathrm{s}^{-1}\end{array}$ & 1992-2018 & https://www.esr.org/research/oscar \\
\hline $\begin{array}{l}\text { Zonal component of geostrophic current } \\
\text { velocity, } \mathrm{m} \mathrm{s}^{-1}\end{array}$ & $1992-2018$ & https://www.esr.org/research/oscar \\
\hline Amount of cyclonic eddies & $1993-2018$ & https://www.aviso.altimetry.fr \\
\hline Amount of anticyclonic eddies & $1993-2018$ & https://www.aviso.altimetry.fr \\
\hline Concentration of dissolved nitrate, $\mu \mathrm{mol} \mathrm{L}^{-1}$ & $1997-2015$ & https://giovanni.gsfc.nasa.gov \\
\hline Concentration of chlorophyll-a, $\mathrm{mg} \mathrm{m}^{-3}$ & $1998-2018$ & https://giovanni.gsfc.nasa.gov \\
\hline Outgoing longwave radiation, $\mathrm{Wm}^{-2}$ & $1948-2018$ & http://www.esrl.noaa.gov/psd/data \\
\hline El-Nino Southern Oscillation index & $1950-2018$ & $\begin{array}{l}\text { https://www.esrl.noaa.gov/psd/data/clim } \\
\text { ateindices/list/ } \\
\text { https://origin.cpc.ncep.noaa.gov/product } \\
\text { s/analysis_monitoring/ensostuff/ONI_v5 } \\
\text {.php }\end{array}$ \\
\hline Indian Ocean Dipole index & $1970-2018$ & $\begin{array}{l}\text { https://www.esrl.noaa.gov/psd/gcos_wgs } \\
\text { p/Timeseries/DMI/http://www.jamstec.g } \\
\text { o.jp }\end{array}$ \\
\hline Sardine landings, $\mathrm{mt}$ & $1988-2018$ & Statistics Book, 2002-2018 \\
\hline Large pelagic landings, $\mathrm{mt}$ & $1988-2018$ & Statistics Book, 2002-2018 \\
\hline Fishing effort & $1988-2018$ & Statistics Book, 2002-2018 \\
\hline
\end{tabular}


Monthly data on landings of large and small pelagic fishes and on the number of boats involved in artisanal fishery were retrieved from the archives of the Ministry of Agriculture and Fisheries. Landings have been recorded by categories entitled in archived materials as "Large pelagics", "Small pelagics", "Demersal", "Unidentified Fishes", etc. Within these categories, fish is distributed over taxonomic groups, such as: "Yellowfin Tuna", "King Fish", "Queenfish", "Sardines", and etc. Data were published annually, in the form of the "Fisheries Statistic Book" (2010-2018). We defined and used "catches" as the sum of "landings" contributed by retained, landed and discarded catch.

Sardines of the Arabian S e a are exposed to the press of large pelagic predators, such as the longtail tuna (Thunnus tonggol (Bleeker, 1851)), sawtooth barracuda (Sphyraena putnamiae (Jordan and Seale, 1905)), kingfish (Scomberomorus commerson Lacepéde,1802), queenfish (Scomberoides commersonnianus Lacepéde,1801), sailfish (Istiophorus platypterus (Shaw, 1792)), and some other species. With this regard, we merged data on landings of large pelagic species and used this parameter in the Principal Component Analysis, to characterize the trophic press imposed on sardines.

The "Statistica" v.9 software was used for the Principal Component Analysis (PCA) and the Spectral Analysis of monthly time series of sardine catches. A Hamming window with weights of $0.04,0.24,0.45$ and 0.04 was applied to a detrended and mean-subtracted monthly time series of sardine catches, in order to estimate the power spectrum of fluctuations, in particular the main period pronounced in 30 year monthly time series. The PASTv.3.25 software (https://www.softpedia.com) was used to run the Mann-Kendall test, in order to assess the validity of interannual trends.

A set of variables subjected to the PCA was contributed by physical, chemical and biological parameters. The biological part was centered on trophic interactions of sardines. On one hand, we considered the food source represented by phytoplankton and variables affecting its variability (namely, the mixed layer depth, photosynthetically active radiation, outgoing long wave radiation, and the concentration of dissolved nitrate). On the other hand, sardines are stressed by large pelagic predators, these catches have been treated as indicators of their biomass in our analysis.

It should be mentioned that the assembled time series of environmental variables were fairly heterogeneous, due to a number of years poorly covered by measurements. With this respect, only the latest 18 years of data (2000-2018), with the most comprehensive estimates, were subjected to the PCA.

\section{RESULTS}

The upper mixed layer of the ocean is the habitat of sardine populations. With this regard the analysis of environmental forces and physical-biological coupling in the upper layer was carried out. Monthly variation of the wind field was broken down into the zonal and meridional components of the speed. The NCEP-NCAR database 
enables one to retrieve data for a relatively broad time range, from the 1950 s to the present time. The seasonal pattern is well pronounced and exhibits the peak of both wind speed components associated with the Southwest Monsoon (SWM). We plotted interannual variations of the wind speed during SWM periods (Figure 1).

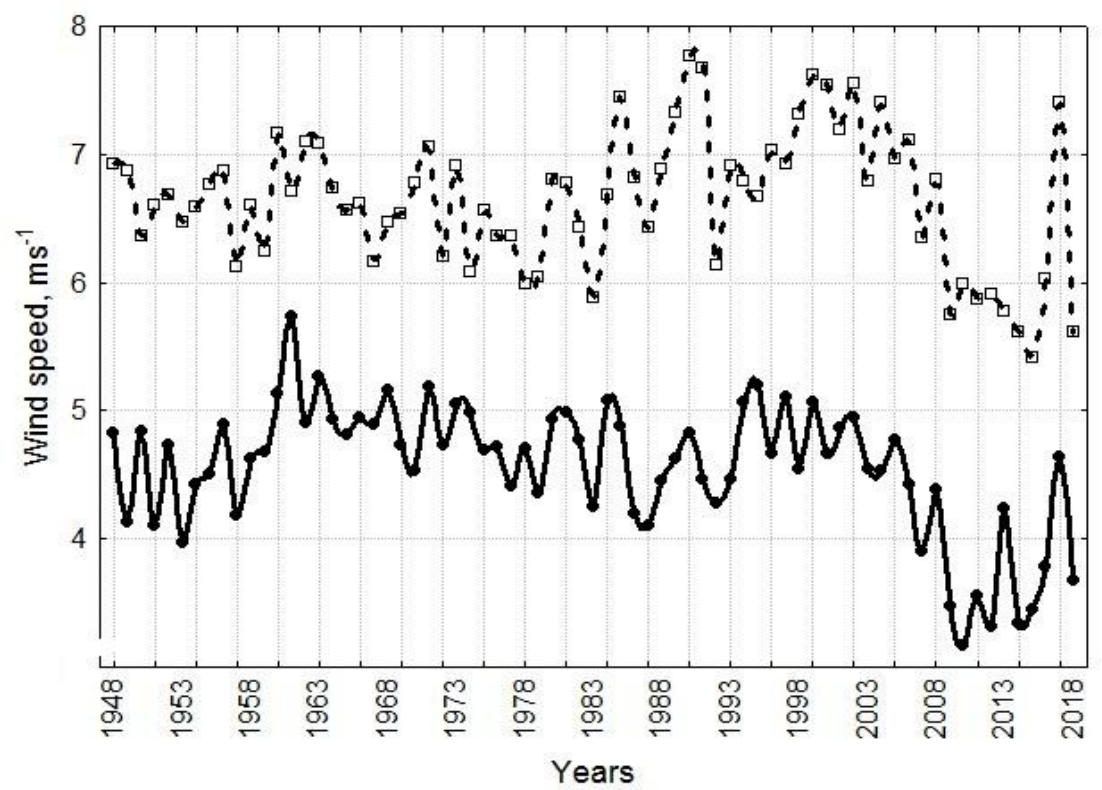

Figure 1. Interannual variations of the wind speed components during the Southwest Monsoon (averaged for June, July and August). The dashed line stands for the meridional component of the wind speed. The solid line stands for the zonal component of the wind speed. Curves were smoothed by a cubic spine.

The decade of 2000-2010, was notorious for a declining trend of the wind speed pronounced in both components (Mann-Kendall test: (a) for meridional component $\mathrm{S}$ $=-98, Z=3.40, p$ (no trend) $=0.0007$; (b) for zonal component $S=-81, Z=2.80, p$ (no trend $)=0.005$ ). Over years, a declining trend of the zonal component was also pronounced during both inter-monsoon seasons $(\mathrm{p}>0.05)$ but not the Northeast Monsoon. It should be noted that the wind speed has been averaged for a large region (the $6^{\circ}$ box over latitude and longitude, covering the Omani shelf and off the coast). The averaging smoothed the spatial heterogeneity of the wind field, which is important in mediating the mesoscale eddies pronounced at the sea surface.

The spatio-temporal distribution of mesoscale eddies in the region was discussed in our previous paper (Piontkovski et al., 2019). With regard to the present study, we updated the interannual trend of eddy occurrence, which confirmed the previously reported pattern of the number of cyclonic and anticyclonic eddies increasing over years, during inter-monsoon seasons. Eddies the size of $\sim 200 \mathrm{~km}$ in diameter have been pronounced in the field of sea surface height anomalies. Also, they affected spatio-temporal variations of sea surface temperature (SST). The monthly occurrence of cyclonic versus anticyclonic eddies was balanced. 
Temperature is believed to be an important environmental factor that influences growth, maturation and survival of small pelagic fishes of the Arabian Sea (Al-Abri et al., 2019). Sardines inhabit the upper mixed layer mostly, which is occupied by the Indian Ocean Water Mass. Due to monsoonal mode of winds, seasonal variations of the temperature in this water mass are substantial. In the past two decades, the minimal SST of $22.18^{\circ} \mathrm{C}$ was recorded in January-2001, while the maximal value attained $32.25^{\circ} \mathrm{C}$ in May-2010. On average, the SST of the SWM, in the western Arabian Sea, 1.8 times exceeded the annual mean temperature. The interannual variation of the SST exhibited two patterns, i.e. the increase of annual means over years and the increase of intra-annual variations of SST over years (Figure 2). The later one points to the intensifying variation of temperature within a seasonal cycle.
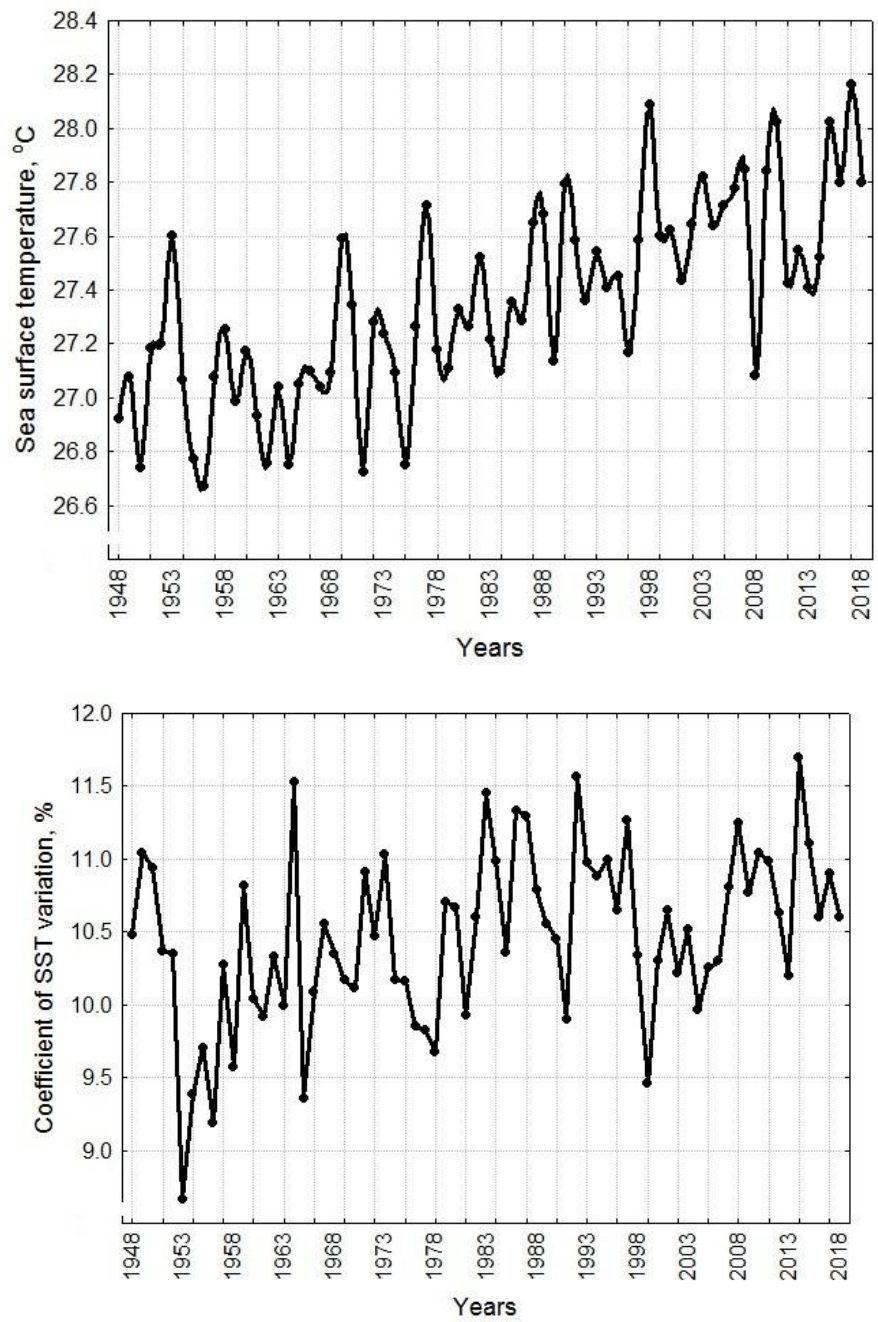

Figure 2. Interannual variations of the sea surface temperature (left panel) and the coefficient of variation of sea surface temperature. The Mann-Kendall trend test for SST: $S=1400, Z=6.96$, $p$ (no trend) $=3.76^{*} 10^{-12}$ ). The Mann-Kendall trend test for the coefficient of variation of SST: $S=617, Z=3.07, p$ (no trend) $=0.002$. Curves were smoothed by a cubic spine. 
The Mann-Kendall trend test implied a statistical significance of both trends. In fact, the observed SST pattern was a projection of a more general pattern of temperature increase over years, which was pronounced in the historical data set assembled for the region. The increase of temperature was observed in the upper $300 \mathrm{~m}$ layer. Our assessments stem from the regional database on CTD casts, from about 90 national and international expeditions described elsewhere (Al-Jufaili and Piontkovski, 2019). For instance, in the upper $50 \mathrm{~m}$ (which is the sardine habitat), the temperature has increased by $2^{\circ} \mathrm{C}$ during the latest six decades (1960-2020), which gives a rate of $\sim 0.3^{\circ} \mathrm{C}$ per decade for the SWM season. A positive trend has also been observed in changes in salinity, which increased by $0.34 \mathrm{ppm}(\sim 0.06$ per decade) during the latest six decades. The Mann-Kendall trend test implied a statistical significance of both trends $(\mathrm{S}=11, \mathrm{p}($ no trend $)=-0.028)$.

Sardine diet in Omani waters is mainly contributed by phytoplankton, which persuaded us to look into the data on nutrients, diatom and chlorophyll- $a$ time series available for the region from the NOBM model. Fragments of these data are shown in Figure 3.
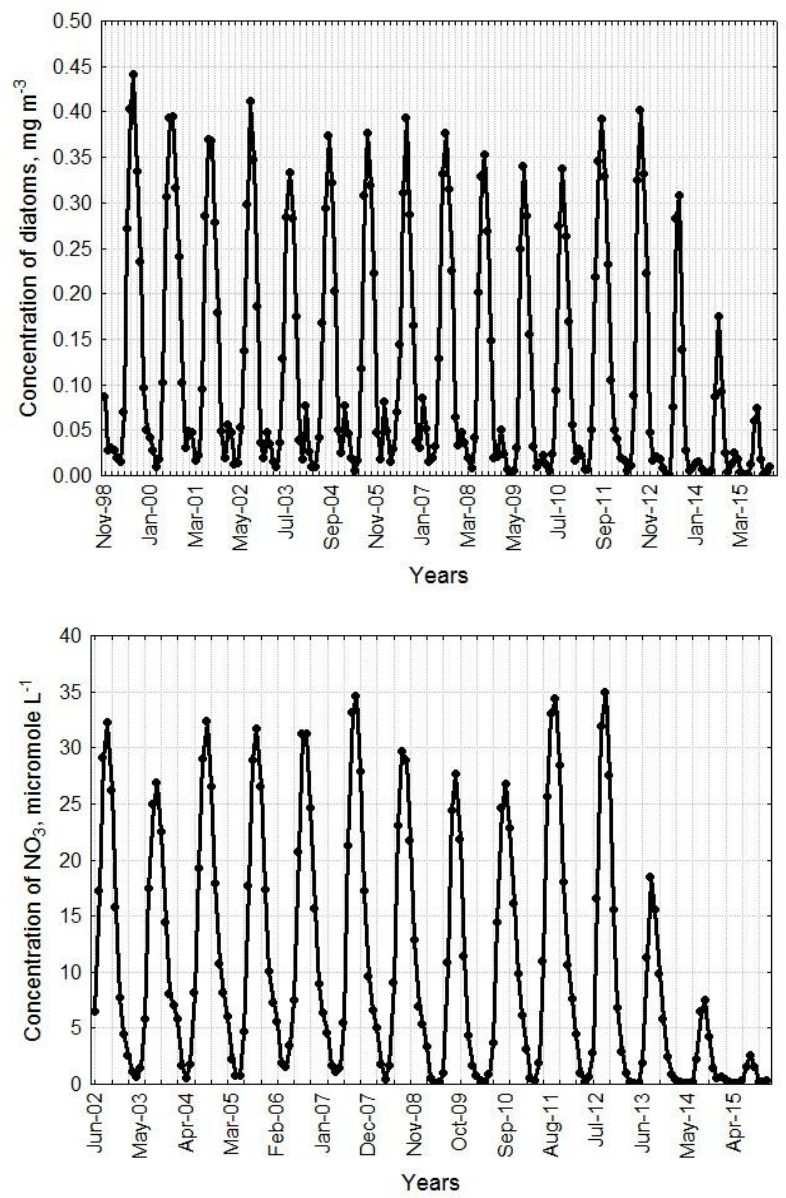

Figure 3. Monthly variations of the concentration of diatoms and nitrates in the upper mixed layer of the western Arabian Sea. 
The fluctuations shown on both plots reflect the seasonality, which is the main pattern, and along with seasonality, a sign of an interannual declining trend, which took place in the latest decade. Unfortunately, the model products are limited to 2015. The chlorophyll- $a$ concentration demonstrated well pronounced seasonality as well, in which the summer peak associated with the SWM exceeds the annual mean values by a factor of three.

The spatial distribution of chlorophyll- $a$ concentration along the Omani shelf was highly heterogeneous within all the seasons. We exemplified the three seasons of 2008, which showed two orders of magnitude variation in the western Arabian Sea (Figure 4),
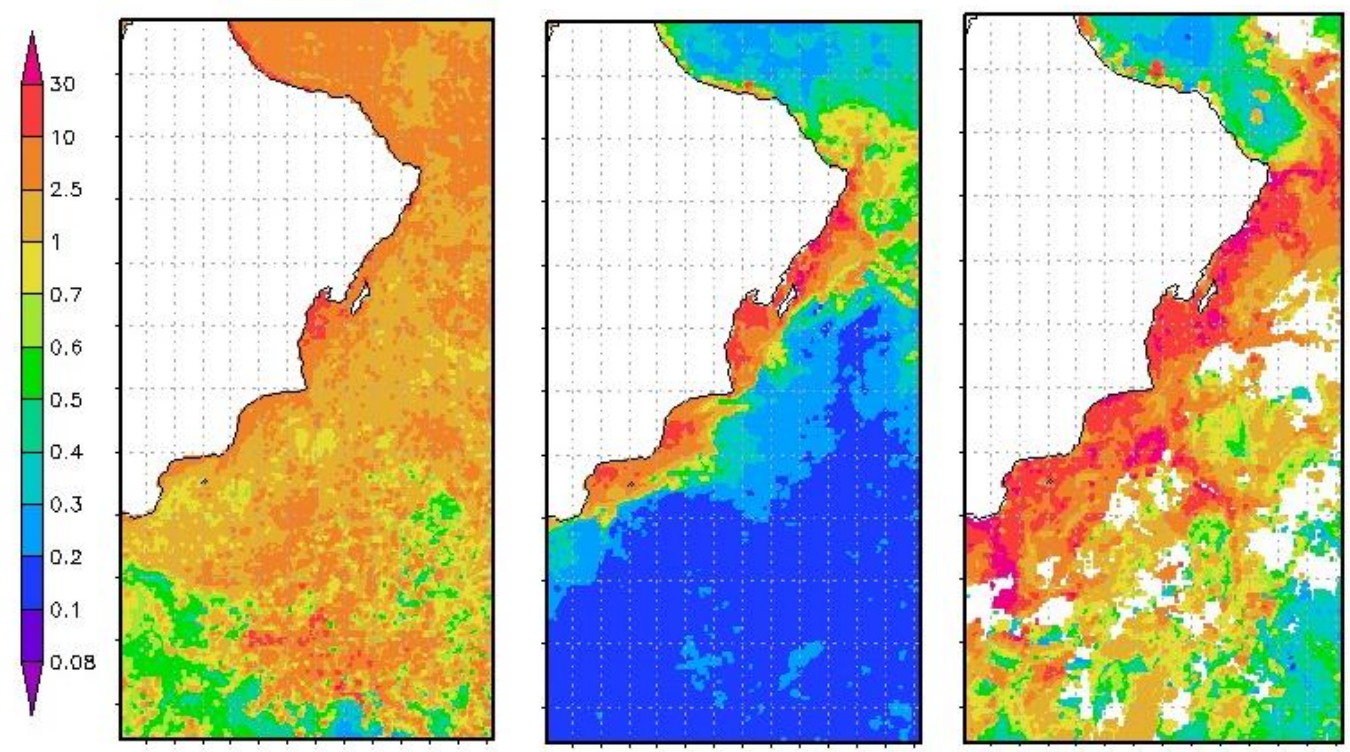

Figure 4. Seasonal variation of the chlorophyll-a concentration in the western Arabian Sea (including the Omani shelf). The vertical color bar stands for the chlorophyll- $a$ concentration $\left(\mathrm{mg} \mathrm{m}^{-3}\right)$. From left to right: Northeast Monsoon (January-February, 2008), Spring Inter-monsoon (April-May, 2008), and Southwest Monsoon (August-September, 2008). White zones in the right figure stand for a cloud mask. Spatial resolution: 4km (MODIS Aqua level 3 products).

The three provinces along the coast (namely, Ash-Sharkiyah, Al-Wusta and Dhofar) are the main contributors to Omani fishery. Provinces differ markedly by the extension of the shelf as well as by the number of fishing boats involved in artisanal landings of sardines. Ash-Sharkiyah has a shelf area of about $6000 \mathrm{~km}^{2}$, followed by Al-Wusta, with $\sim 8,000 \mathrm{~km}^{2}$ and Dhofar, with $17,000 \mathrm{~km}^{2}$. The number of boats over provinces, averaged for the period of 2000-2018, was 617, 405 and 86 respectively. Sardine catches and fishing effort were seasonal, in all three provinces. Due to rough weather conditions, the number of boats operating during the SWM was less compared to the spring and fall inter-monsoon seasons (Figure 5). For comparison, it might be noted that the weather factor is not substantial to the Sea of Oman fishery (in 
Muscat and Al-Batinah provinces), in which the number of boats stays almost invariant over seasons.

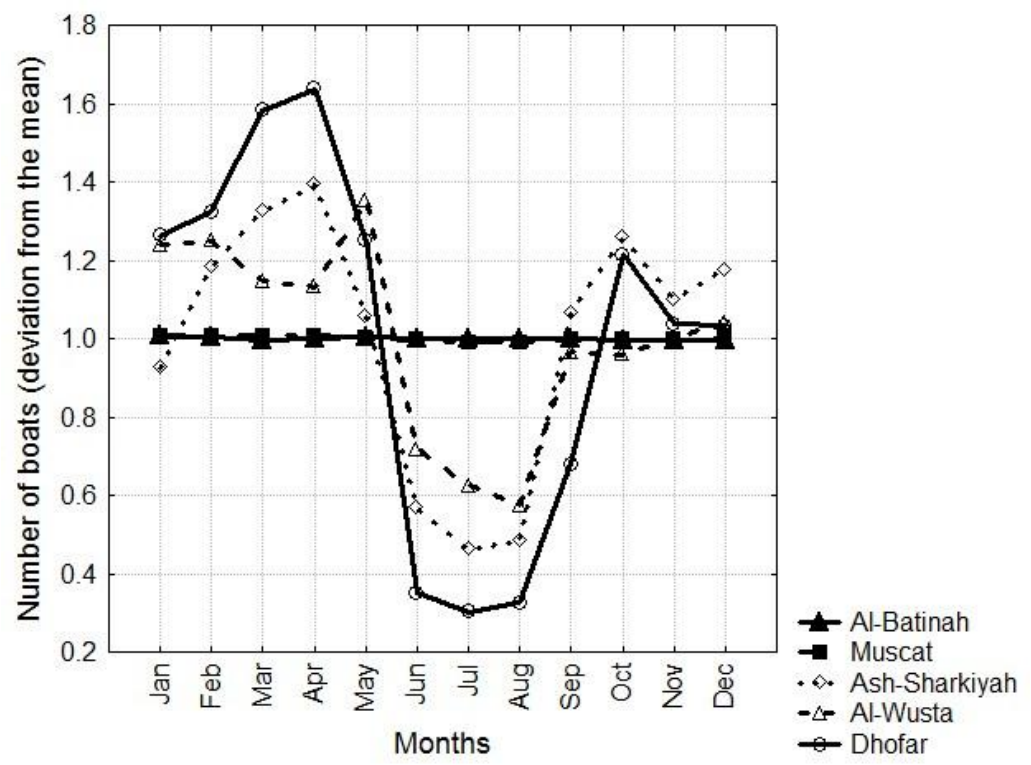

Figure 5. Seasonal variations of fishing efforts over provinces (2007-2018). Y-axis: monthly number of boats/annual mean.

Seasonal variations of sardine catches persist on a positive trend of inter-annual landings observed through all the provinces (Figure 6). Over the past eight years, for instance, the catch per unit of effort (CPUE) in Dhofar, Al-Wusta and Ash-Sharkiyah increased by a factor of 4,12 and 5 , respectively.
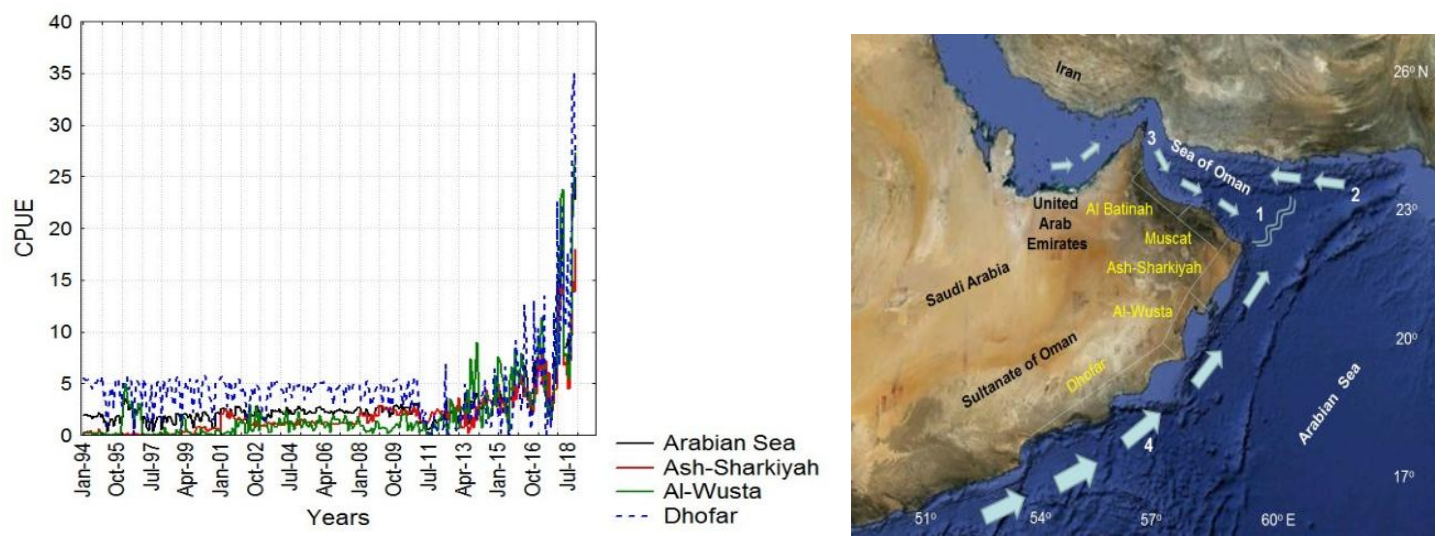

Figure 6. Monthly variations of sardine catches along the Omani shelf. Upper panel: monthly time series of CPUE over three provinces and the western Arabian Sea as the whole. Low panel: a scheme of geostrophic currents during SWM and a threedimensional bathymetric map (www.earth.google.com). Two parallel zigzags (1) demarcate the location of the Ras Al Hadd frontal zone formed by the confluence of the East Oman Current (3) and Oman Coastal Current (4). Arrows (2-4) indicate direction of currents during the Southwest Monsoon. (2): inflow of the Indian Ocean Water mass, (3): outflow of the Persian Gulf Water mass. 
An increase in sardine CPUE has been accompanied by increasing monthly variations of CPUE, which have been observed in all three provinces during the latest decade, as well as in the whole studied region (named as "Arabian Sea" in Figure 6). The spectral analysis of 30 years detrended and mean-subtracted monthly time series (not shown here) implied dominant periods of three and one year, pronounced in CPUE averaged for the whole studied region $\left(16-22^{\circ} \mathrm{N}, 54-60^{\circ} \mathrm{E}\right)$.

Along with the aforementioned environmental factors, the trophic stress imposed on sardines by large pelagic species should be analyzed. With these regards, monthly data on landings of all large pelagic species (merged) and the number of boats were converted to the CPUE and incorporated into the Principal Component Analysis. Among all the factors subjected to PCA, the El Niño-Southern Oscillation index and the Indian Ocean Dipole index acted as indicators of the global scale and the basin scale anomalies affecting regional circulation. In general, interannual variations of the sea surface temperature in the tropical Indian Ocean are forced by the surface heat flux variations remotely driven from the tropical Pacific through the El-Niño Southern Oscillation (Shinoda et al., 2004). The El Niño-Southern Oscillation (ENSO) is generated by fluctuations in the equatorial Pacific, between warmer than normal sea surface temperatures in the eastern equatorial Pacific (corresponding to the El-Niño phase) and cooler than normal temperatures in the central equatorial Pacific (the LaNiña phase). ENSO is believed to be the most powerful phenomenon affecting the globe. Since 2000, six ENSO have been observed.

The Indian Ocean Dipole (IOD) also mediates interannual variability in the Arabian Sea. The intensity of IOD used to be identified by the sea surface temperature gradient between the western equatorial Indian Ocean $\left(50^{\circ} \mathrm{E}-70^{\circ} \mathrm{E}\right.$ and $\left.10^{\circ} \mathrm{S}-10^{\circ} \mathrm{N}\right)$ and the southeastern equatorial Indian Ocean $\left(90^{\circ} \mathrm{E}-110^{\circ} \mathrm{E}\right.$ and $\left.10^{\circ} \mathrm{S}-10^{\circ} \mathrm{N}\right)$. This gradient characterizes anomalous cooling of sea surface temperature in the southeastern region and anomalous warming in the western one (Saji et al., 1999).

The Principal Component Analysis elucidated three statistical eigenvectors (Factor1, Factor 2 and Factor3), which explained $71 \%$ of the total variability in the system of proposed environmental variables (Table. 2). 
Table 2. Factor loading and statistical coupling in interannual variations of selected parameters. Eigenvalues: 5.26, 4.11 and 3.90. Statistically significant loadings exceeding 0.7 are marked in bold.

\begin{tabular}{|l|c|c|c|}
\hline \multicolumn{1}{|c|}{ Variables } & F1 & & \\
& $(28 \%)$ & F2 (22\%) & F3 (21\%) \\
\hline Large pelagic species (CPUE) & $\mathbf{- 0 . 7 6}$ & -0.04 & -0.18 \\
\hline Sardines (CPUE) & $\mathbf{0 . 8 4}$ & 0.17 & -0.30 \\
\hline Atmospheric pressure gradient at sea surface & -0.26 & 0.44 & 0.69 \\
\hline Sea surface temperature (western part) & 0.07 & $\mathbf{- 0 . 7 6}$ & -0.61 \\
\hline Sea surface temperature (eastern part) & 0.14 & $\mathbf{- 0 . 9 2}$ & -0.17 \\
\hline Sea surface temperature gradient (west-east) & -0.07 & -0.02 & $\mathbf{- 0 . 8 1}$ \\
\hline Zonal component of the wind speed & $\mathbf{- 0 . 7 5}$ & 0.37 & -0.15 \\
\hline Meridional component of the wind speed & $\mathbf{- 0 . 8 2}$ & -0.06 & -0.07 \\
\hline Concentration of chlorophyll-a & -0.29 & 0.60 & -0.22 \\
\hline Meridional component of the current velocity & -0.15 & 0.30 & $\mathbf{- 0 . 8 5}$ \\
\hline Zonal component of the current velocity & 0.23 & 0.75 & -0.39 \\
\hline Cyclonic eddies & $\mathbf{0 . 7 7}$ & 0.11 & 0.32 \\
\hline Anticyclonic eddies & 0.64 & -0.05 & 0.37 \\
\hline Photosynthetically available radiation & 0.28 & -0.05 & -0.01 \\
\hline Mixed layer depth & 0.49 & 0.69 & -0.03 \\
\hline Concentration of dissolved nitrates & $\mathbf{- 0 . 8 1}$ & -0.04 & 0.36 \\
\hline Outgoing longwave radiation & -0.67 & -0.23 & 0.10 \\
\hline El-Niño-Southern Oscillation index & 0.16 & -0.36 & $\mathbf{- 0 . 8 1}$ \\
\hline Indian Ocean Dipole index & 0.13 & $\mathbf{- 0 . 8 0}$ & 0.52 \\
\hline
\end{tabular}

As the variable, sardines have contributed to the Factor1, in which statistical linkages of sardines with large pelagic predators, wind speed, cyclonic eddies and concentration of dissolved nitrates formed the major factor load (28\%). Sardines and large pelagic species were the most powerful contributors, with opposite signs, which placed these variables in opposite parts of the F1 vs F2 factor plane. The only variable 
of Factor1 sardines teamed with (by a positive sign), was the amount of cyclonic eddies. In fact, both types of eddies (cyclonic and anticyclonic) form the cluster, which may be illustrated by the projection of variables on the factor plane (Figure 7).

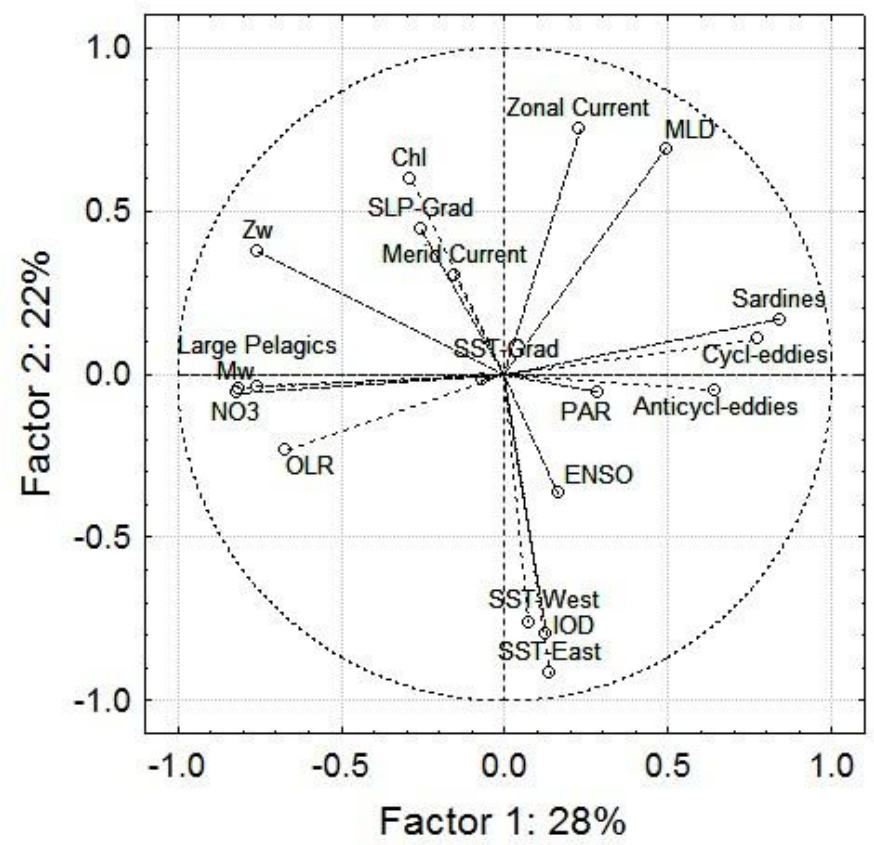

Figure 7. The projection of variables on the factor plane. Abbreviations. Zw: zonal component of the wind speed, Mw-meridional component of the wind speed, SSTEast: sea surface temperature (eastern part of the region), SST-West: sea surface temperature (western part of the region), SST-Grad: sea surface temperature gradient between western and eastern parts, PAR: photosynthetically available radiation, OLR: outgoing long wave radiation, SLP-Grad: atmospheric pressure gradient at sea surface, Merid.Current: meridional component of geostrophic current velocity, Zonal Current: zonal component of geostrophic current velocity, MLD: mixed layer depth, NO3: concentration of dissolved nitrates, Chl: concentration of chlorophyll- $a$, Cycleddies: number of cyclonic eddies in the region, Anticycl-eddies: number of anticyclonic eddies in the region, IOD: Indian Ocean Dipole index, ENSO: El NiñoSouthern Oscillation index, Large Pelagic: total CPUE of large pelagic species.

The sea surface temperature and IOD form the other well pronounced cluster which contributes to Factor 2. Overall, Factors 2 and 3 contributed equally ( $22 \%$ and 21\%), to the total variability. The range of sea surface temperature drives the offshoreinshore migrations of sardines. Optimal temperatures are located between $26^{\circ} \mathrm{C}$ and $28^{\circ} \mathrm{C}$. Schools abandon the upper layer when the temperature exceeds $29^{\circ} \mathrm{C}$ (Chidambaram, 1950). In this respect, the annual sea surface temperatures of the latest decade as well as the coefficient of their variation point to the possibility of sardine populations being associated with coastal waters more closely than in the previous decade (Figure 2). 
The Indian Ocean Dipole and the El Niño-Southern Oscillation index were notorious contributors to F2 and F3. It should be noted that the time series of both indices were retrieved from the period of spring inter-monsoon - which is the time of maximal sardine catches. Taking into account the marked role of both atmospheric oscillations, we plotted sardine catches (CPUE) as the function of two indices (Figure 8, left panel).
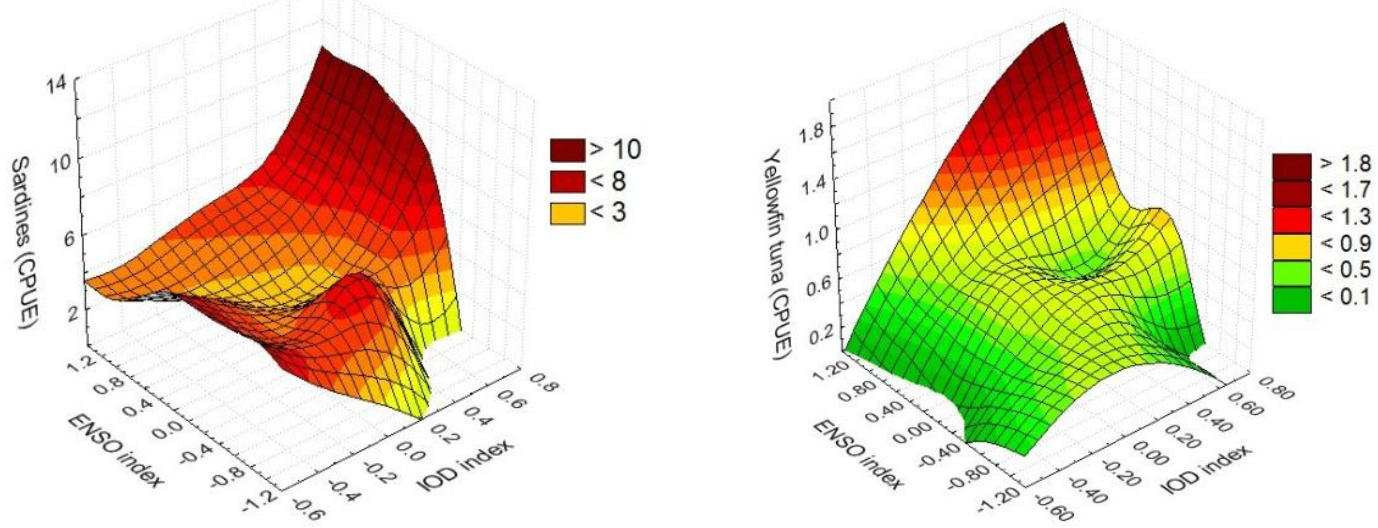

Figure 8. Relationship between sardine catches (left panel), yellowfin tuna catches, El-Niño Southern Oscillation, and Indian Ocean Dipole index (1988-2018). Diagrams were smoothed by the Distance Weighted Least Squares method. The right panel figure is taken from Al-Jufaili and Piontkovski (2019).

The three-dimensional plot of coupling illustrates the situation in which the highest catches take place when the ENSO and IOD both approach their medium to full strength positive phase (0.4-1.4 ENSO index values and 0.4-0.8 IOD values). This plot was compared with the similar one, characterizing the Yellowfin tuna catches (Al-Jufaili and Piontkovski, 2019). The highest catches of this species take place in the years when the ENSO index corresponds to the range of 0.8-1.2 while the IOD index exhibits the range of 0.6-0.8.

\section{DISCUSSION}

Seasonal and interannual variations of catches incorporate a human-induced and an environmental component. In Oman, an artisanal fishing effort could be estimated, most accurately, for the latest three decades (1988-2018). Over 90\% of vessels were fiberglass boats, 5-9 m long. In Ash-Sharkiyah, Al-Wusta, Dhofar, a three to four fold increase of fishing efforts was observed (Fishery Statistics Book, 2011, 2013, 2018). Overfishing, related to fishing effort, depends upon the market demand. For instance, the Yellowfin tuna stock in the Indian Ocean is overfished (IOTC, 2018; http://firms.fao.org/firms/resource/22/en), while the Indian oil sardine is less stressed, due to less valuable contribution to the revenue, as well as high reproductive 
properties of sardine populations.

As for environmental factors, a positive interannual trend and the magnitude of seasonal fluctuations, which increased gradually during the latest decade, have been the two main patterns we denoted, in analyzing monthly time series on sardine catches (CPUE).

Presumably, an increase in the magnitude of seasonal fluctuations in sardine catches over years was associated with an increase of the magnitude of sea surface temperature fluctuations (Figure 2), accompanied by a decline of the wind speed (Figure 1), increased occurrence of mesoscale eddies (Al-Jufaili and Piontkovski, 2019) and declined concentration of diatoms (Figure 3) which contribute gradually to the sardine diet (Jayaprakash and Pillai, 2000; Remya et al., 2013). All the above processes could have stimulated sardines to undertake intensive alongshore and offshore migrations footprinted in the form of enhanced magnitudes of catches. The distances of sardine feeding migrations could be thousands of kilometers (Schwartzlose et al., 1999; Wada and Kashiwai, 1991) and are believed to be ruled by changes of the preferential temperature zones and predator press (Armstrong et al., 1991; O’Donoghue et al., 2010).

On the opposite side of the Arabian Sea, along the Indian shelf, the sea surface temperature range below the physiological optimum forces sardine to migrate. In this respect, a correlation was found between the sea surface temperature and landings of oil sardine along the Indian coast with well pronounced temperature gradients, from the North to the South (Vivekanandan et al., 2009). The thermal range of the Indian oil sardine populations is located between $22^{\circ} \mathrm{C}$ and $28^{\circ} \mathrm{C}$ (https://www.fishbase.de/Summary/SpeciesSummary.php?ID=1511\&AT=indian+oil+ sardine). The range of temperatures in the western Arabian Sea observed during the latest decade (Figure 2) and the coefficient of variation of these temperatures exceeded the optimum reported for sardines and thus has stimulated migrations.

The PCA identified a number of environmental variables which contributed markedly to interannual variations of sardine catches, namely the wind speed, sea surface temperature, geostrophic current velocity, number of cyclonic eddies, two large scale atmosphere driven oscillations -the ENSO and IOD, and the total catch of large pelagic species (predators on sardines). Moreover, the three year period pronounced in fluctuations of sardine catches (according to the Spectral Analysis) was reported in the fluctuations of the multivariate ENSO index (Piontkovski and Chiffings, 2014).

A number of other studies emphasized the role of the aforementioned parameters in spatio-temporal variability of sardine catches. In particular, in the California Current, the elevated concentrations of sardine larvae were associated with cyclonic eddies and the peripheries of anticyclonic eddies, which are believed to be favorable areas for sardine recruitment (Logerwell and Smith, 2001; Logerwell et al., 2001). Warm eddies could often branch out warm streamers well seen in satellite images of sea surface temperature with streamer structures of about $10 \mathrm{~km}$ in width. Simultaneous satellite measurements and aircraft observations on sardine schools have shown that sardines tend to use warm streamers for migration towards the coast, with the 
formation of dense schools at the head of warm streamers, in which fishing grounds are often formed (Sugimoto and Tameishi, 1992; Tameishi et al., 1994).

In our case, sardine catches exhibited a statistical association with cyclonic (cold) eddies, although the anticyclonic ones have been standing very close to the cyclonic, by contribution to the Factor 1 and have had the same sign (Table 2). Cyclonic eddies of the western Arabian Sea have well pronounced chlorophyll maxima, in their central parts (Tang et al., 2002). Presumably, these maxima could attract sardine schools. Sampling along the transects directed offshore from the Omani shelf, implied diatoms to be dominant during summer coastal upwelling (Latasa and Bidigare, 1998). In the later field surveys over the continental slope and the western open sea waters, in February and March, diatoms from genera Rhizosolenia, Thalassiotrix, Nitzschia, and Chaetoceros, accounted for $\sim 80-98 \%$ of the total phytoplankton biomass in the upper $100 \mathrm{~m}$ layer. In cyclonic eddies, the total phytoplankton biomass exceeded that of anticyclonic eddies by as much as 5-6 times (Kuzmenko, 2006).

An increase in the number of eddies in the western Arabian Sea (Piontkovski et al., 2019) makes the upper layer increasingly heterogeneous, by physico-chemical properties. An increasing (over years) coefficient of variation of SST reflects this event (Figure 2).

The gut content analysis of the sardines caught in coastal waters of Muscat and Sohar (the Sea of Oman) has indicated that phytoplankton could comprise up to $68 \%$ of their diet (Haleem et al., 2011). In the eastern Arabian Sea, in coastal waters of India, the remotely sensed chlorophyll- $a$ could explain up to $39 \%$ of interannual variations in sardine landings (George et al., 2012). However, no direct correlation was found between the CPUE of sardines and remotely sensed chlorophyll- $a$ (averaged for the studied area and analyzed in the form of annual means in our study). The PCA did not reveal the chlorophyll- $a$ as a statistically significant parameter, either, although chlorophyll- $a$, with the loading value of 0.6 in F2, was close to the statistically significant level (0.7) marked in bold, in Table 2. Also, statistically significant coupling between chlorophyll- $a$ and sardines was pronounced in the Sea of Oman, in the data of the previous decade (Piontkovski et al., 2014).

A depleted contribution of chlorophyll- $a$ to PCA loading could be explained, in part, by huge winter algal blooms caused by the dinoflagellate Noctiluca scintillans in the western Arabian Sea. This species is actively avoided by sardines (Nair, 1958) and Noctiluca has not been reported in their stomachs (Prasad, 1953; Sekharan, 1966). Being a heterotrophic organism feeding on small phytoplankton, Noctiluca competes for food with sardines. Periodically, endosymbionts of Noctiluca contribute markedly to remotely sensed chlorophyll- $a$ and distort the ocean color (hence remotely sensed chlorophyll-a concentration) contributed by the other phytoplankton groups. The Noctiluca blooms dominate the northern part of the western Arabian Sea and are less pronounced in the southern part. In this respect, monthly fluctuations of chlorophyll- $a$ in these parts (which we analyzed separately, for the Ash-Sharkiyah and Dhofar provinces, along with the whole western Arabian Sea region) were not correlated. This affected the correlation between sardines and 
chlorophyll- $a$ on the scale of the whole western Arabian Sea.

The El-Niño Southern Oscillation and Indian Ocean Dipole play a notorious role in long-term variations of the sea surface temperature in the tropical Indian Ocean (Saji et al., 1999), although coupling between these oscillations is yet to be understood in detail. The ENSO-induced anomalous circulation over the Arabian Sea could be either countered or supported by the Indian Ocean Dipole, depending on the state of the phase and the amplitude of the two (Charabi and Abdul-Wahab, 2009). The diagrams we proposed (Figure 8), characterized the diversity of the scenario of coupling between the El-Niño Southern Oscillation, Indian Ocean Dipole and fish catches along the Omani shelf. The shape of diagrams points to a certain "match-mismatch" situation in the interplay of three variables. Because IOD and ENSO phases are not correlated, the occurrence of "the match situation", which results in maximal catches, is difficult to predict.

IOD and ENSO also impact the variables which the PCA has contoured as statistically significant in variations of sardine catches. In the southeast Indian Ocean, for instance, the interannual variation of eddy occurrence was associated with their kinetic energy, which was mediated by fluctuations of regional currents. In turn, the intensity of these currents was modulated by the Indian Ocean Dipole, the Southern Annular Mode, and the El-Niňo Southern Oscillation (Jia et al., 2011).

On the opposite side of the Arabian Sea, a negative trend of sardine landings observed during the latest six years over the shelf of Kerala (India) was reported (Sajna et al., 2019). Kerala is the major producer of oil sardine, with landings about one order of magnitude higher than in Oman (FAO, 2016). The peak of landing in 2012 (mediated by an almost 4 fold increase in fishing effort) was followed by a gradual decline, up to the present time. The factors driving this decline were rainfalls, series of weak monsoons and the 2015 ENSO resulted in warmer waters which negatively affected the maturation of sardine larvae and the enhanced abundance of jellyfish which suppressed the recruitment after 2013 (Kripa et al., 2018).

Details of the mechanisms driving opposite trends of sardine catches on opposite sides of the Arabian Sea are yet to be elucidated. We assume that the "match-mismatch situation", which stems from the interplay between sardine catch, ENSO and IOD on both sides, is one of the important constituents for comparison. In a broader context, the phenomenon of synchronized (over various geographic regions and oceans) or out of phase fluctuations in sardine landings have been discussed and related to the global scale climate driven events (Schwartzlose et al., 1999).

In the 30 year historical record we analyzed, the latest decade of sardine catches has exhibited a huge peak. The next several years of catches would contour the period of this peak. This expectation bolds the issue of the characteristic period pronounced in interannual fluctuations of sardine catches along the Omani shelf. For instance, data from the Pacific Ocean implied a period of about 50 years, in sardine landings (Chavez et al., 2003). Reconstruction of the history of pacific sardine biomass over the past two millennia from sediments showed that sardines tend to vary over a period of about 60 years (Baumgartner et al., 1992). 
Once interannual variations of sardine landings over the Omani shelf are driven by a complex coupling of several factors (discussed in this paper), one might expect a characteristic period of variations to be mediated by interplay of these factors. Nonetheless, the interannual variations footprinted in historical records of landings do not exhibit a sign of these kinds of periods in the western Arabian Sea. As for the eastern side, recent predictions under the climate-driven IPCC model RCP 4.5, implied a general decline of Indian oil sardine catches along the Kerala coast, after 2049 till 2070s. The model revealed the increase of sea surface temperature to be one of the major factors affecting the distribution and abundance of sardines (Sajna et al., 2019).

\section{CONCLUSIONS}

An increase of the catch per unit of effort (in the past decade) and an increase of the magnitude of seasonal fluctuations of these catches have been the main trends pronounced in a 30-year time series of sardine catches.

The wind speed, sea surface temperature, geostrophic current velocity, number of cyclonic eddies, the El-Niño Southern Oscillation, Indian Ocean Dipole, and large pelagic species (predators on sardines) were the environmental variables which modulated interannual variations of sardine catches along the Omani shelf overlooking the western Arabian Sea. The relationship between catches, El-Niño Southern Oscillation and Indian Ocean Dipole index pointed to a certain "numeric match" of two atmosphere driven anomalies that should happen, to favor maximal catches of sardines in the western Arabian Sea.

\section{ACKNOWLEGMENTS}

This research was funded by SQU grant \# IG/AGR/FISH/17/01. The authors would like to thank colleagues from the Ministry of Agriculture and Fisheries (Oman) for providing data and consultations on fish catches.

\section{REFERENCES}

[1] Al-Abri, N.M., Piontkovski, S.A., Rabbaniha, M., Al-Abri, M., and Chesalina, T., 2019, Abundance and diversity of fish larvae assemblages in Omani coastal waters of Salalah region (the Arabian Sea). International Journal of Oceans and Oceanography, 13, 2, pp. 325-341.

[2] Al-Jufaili, S., and Al-Jahwari, O., 2011, The Omani coastal traditional sardine fishery 1994-2007: a review. Agricultural and Marine Sciences, 16, pp. 1-12.

[3] Al-Jufaili, S.M., 2007, Conceptual model for sardine and anchovy inverse cyclic behavior in abundance. Journal of Food, Agriculture \& Environment, 5, pp. 317-327.

[4] Al-Jufaili, S.M., Al-Azri, A.R., and Al-Shuaily, S.S., 2006, A Preliminary 
Investigation on the Omani Sardines and Anchovies Stock Fluctuation; Recommendations for Future Studies. Pakistan Journal of Biological Sciences, 9, pp. 1073-1082.

[5] Al-Jufaili, S., and Piontkovski, S.A., 2019, Seasonal and interannual variations of Yellowfin Tuna catches along the Omani shelf. International Journal of Oceans and Oceanography,13, 2, pp.427-454.

[6] Armstrong, M. J., Chapman, P., Dudley, S. F. J., Hampton, I., and Malan, P. E., 1991, Occurrence and population structure of pilchard Sardinops ocellatus, round herring Etrumeus whiteheadi and anchovy Engraulis capensis off the east coast of southern Africa. South African Journal of Marine Sciences, 11, pp. 227-249.

[7] Arur, A., Krishmam, P., George, G., Bharathi, M.P.G., Kaliyamoorthy, M., Shaeb, K.H.B., Suryavanshi, A.S., Kumar, T.S., and Joshi, A.K., 2014, The influence of mesoscale eddies on commercial fishery in the coastal waters of the Andaman and Nicobar Islands, India. International Journal of Remote Sensing, 35, 17, pp. 6418-6443.

[8] Baumgartner, T. R., Soutar, A., and Ferrira-Bartina, V., 1992, Reconstruction of the history of pacific sardine and northern anchovy populations over the past two millennia from sediments of the Santa Barbara basin, California. CalCOFI Report, 33, pp. 24-40.

[9] Charabi, Y, and Abdul-Wahab, S.A., 2009, Synoptic aspects of the summer monsoon of southern Oman and its global teleconnections Journal of Geophysical Research, 114, D07107, doi:10.1029/2008JD010234.

[10] Chavez, F. P., J. Ryan, S., Lluch-Cota, E., and Niquen, M., 2003, From anchovies to sardines and back: multidecadal change in the Pacific Ocean. Science, 299, pp. 217-221.

[11] Chelton, D.B., Schlax, M.G., and Samelson, R.M., 2011, Global observations of nonlinear mesoscale eddies. Progress in Oceanography, 91, pp. 167-216.

[12] Chidambaram, K., 1950, Studies on the length frequency of oil sardine, Sardinella longiceps Cuv.\&Val. and on certain factors influencing their appearance on the Calicut coast of the Madras Presidency. Proceedings of Indian Academy of Sciences, 31, pp. 252-286.

[13] Dorr III, J.A., Al-Bulushi, M., Al-Hijri, M., and Al-Lawatiya, M., 1990, Stock assessment and management of Sardinella longiceps in the Sultanate of Oman. Research Report. Marine Science and Fisheries Center. Ministry of Agriculture and Fisheries. Muscat, Sultanate of Oman.

[14] FAO, 2016, Fishery and Aquaculture Statistics Yearbook, 2014, Food and Agriculture Organization, 105. Rome.

[15] Fishery Statistics Book, 2011, Sultanate of Oman. Ministry of Fisheries. Muscat, 156p.

[16] Fishery Statistics Book, 2013, General Directorate of Planning \&Development. Fisheries Statistics Department. Ministry of Agriculture and 
Fisheries. Muscat, 248p.

[17] Fishery Statistics Book, 2018, General Directorate of Planning \&Development. Fisheries Statistics Department. Ministry of Agriculture and Fisheries. Muscat, 240p.

[18] Gauthier, S., Dunford, A., Macaulay, G., O’Driscoll G., and Divine, J., 2009, NIWA survey-Fish resources assessment survey of the Arabian Sea coast of Oman. Technical Report 3, Small pelagic fish resources of the Arabian Sea coast of Oman. Bruce Shallard and Associates, 319 p.

[19] George, G., Meenakumari, B., Raman, M., Kumar, S., Vethamony, P., Babu, M., and Verlecar, X., 2012, Remotely sensed chlorophyll: a putative trophic link for explaining variability in Indian oil sardine stocks. Journal of Coastal Research, 28, pp. 105-113.

[20] Gregg, W.W., 2008, Assimilation of SeaWiFS ocean chlorophyll data into a three-dimensional global ocean model. Journal of Marine Systems, 69, pp. 205-225.

[21] Gregg, W.W., and Casey, N., 2007, Modeling cpccolithophores in global oceans. Deep Sea Research, part II, 54, pp. 447-477.

[22] Haleem, S. Z. A., Jayabalan, N., Al-Kiyumi, F., Al-Kharusi, L., Al-Habsi, S., and Al-Marzouqi, A., 2011, Fishery, biology and population dynamics of three small pelagic fish species (Indian oil sardine Sardinella longiceps, Indian mackerel Rastrelliger kanagurta and Indian scad Decapterus russeli) from the Sultanate of Oman. Project Final Report, Part II, p. 126-167. Marine Science and Fisheries Center, Ministry of Agriculture and Fisheries Wealth, Muscat.

[23] Jayaprakash, A.A., and Pillai, N.G.K., 2000, The indian oil sardine. In: "Marine fisheries research and management" (V.N.Pillai and N.G.Menon, eds). Central Marine Fisheries Research Institute, Kerala, India, pp. 259-291.

[24] Jia,F., Wu, L., Lan, J., and Qiu, B., 2011, Interannual modulation of eddy kinetic energy in the southeast Indian Ocean by Southern Annular Mode. Journal of Geophysical Research, 116, C02029, doi:10.1029/2010JC006699.

[25] Johannesson, K.A., 1995, Oman fish resources assessment survey. Assessment of major marine fish stocks of demersal, small pelagic and mesopelagic species. R/V Rastrelliger acoustic ad trawling survey results. November 1989 - November 1990. FAO/UNDP Project. (FI:DP/OMA/88/005 Technical Report 1), Oman Resources Assessment Survey.

[26] Khalfallah, M., Zylich, K., Zeller, D., and Pauly, D., 2016, Reconstruction of domestic marine fisheries catches for Oman (1950-2015). Frontiers in Marine Science, 3, article 152, doi:10.3389/fmars.2016.00152.

[27] Kistler, R., Kalnay, E., Collins, W., Saha, S., White, G., Woollen, J., Chelliah, M., Dool, W., Jenne, R., and Fiorino, M., 2001, The NCEP-NCAR 50-Year Reanalysis: Monthly Means CD-ROM and Documentation. Bulletin of the American Meteorological Society, 82, pp. 247-268. 
[28] Kripa, V.,.Kolliyil, M, Koya, K.P.S., Jeyabaskaran, R., Prema, D., Padua, S., Kuriakose, S., Anilkumar, P.S., Preetha, G.N., Ambrose, T.V., Dhanya, A.M., Abhilash, K.S, Bose, J., Divya, N.D., Shara, A.S. and Vishnu, P.G., 2018, Overfishing and climate drives changes in biology and recruitment of the Indian Oil Sardine Sardinella longiceps in the southern Arabian Sea. Frontiers in Marine Science, 5: 443; doi:10.3389/fmars.2018.00443.

[29] Kripa, V., D., Prema, R., Jeyabaskaran, L. R., Khambadkar, A., Nandakumar, P. S., Anilkumar, T., Ambrose, V., Bose, J., Preetha, G.N., and Pillai, V. N., 2015, Inter-annual variations of selected oceanographic parameters and its relation to fishery of small pelagics off Kochi, southwest coast of India. Journal of Marine Biological Association of India, 57, 2, pp. 1861-1878.

[30] Kuzmenko, L.V., 2006, The phytoplankton level in the ecosystem of the Arabian Sea. In: "The mesoscale structure of the epipelagic ecosystem of the open northern Arabian Sea". K.Banse and S.A.Piontkovski (Eds.), Universities Press, Hyderabad, pp. 93-114.

[31] Latasa, M., Bidigare, R.R., 1998, A comparison of phytoplankton populations of the Arabian Sea during the Spring Intermonsoon and Southwest Monsoon of 1995 as described by HPLC-analyzed pigments. Deep-Sea Research, II, 45, pp. 2133-2170.

[32] Logerwell, E., Lavaniegos, B., and Smith, P., 2001, Spatially-explicit bioenergetics of Pacific sardine in the Southern California Bight: are mesoscale eddies areas of exceptional prerecruit production? Progress in Oceanography, 49, pp. 391-406.

[33] Logerwell, E., and Smith, P., 2001, Mesoscale eddies and survival of late stage Pacific sardine (Sardinops sagax) larvae. Fisheries Oceanography, 10, pp. 13-25.

[34] Longhurst, A. R., and Wooster, W. S., 1990, Abundance of oil sardine (Sardinella longiceps) and upwelling on the southwest coast of India. Canadian Journal of Fisheries and Aquatic Sciences, 47, pp. 2407-2419.

[35] Longhurst, A., 1998, Ecological geography of the sea. Academic Press, N.Y., 398pp.

[36] Lluch-Belda, D., Crawford, R.J.M., Kawasaki, T., MacCall, A.D., Parrish, R.H. and. Schwartzlose, R.A., 1989, Worldwide fluctuations of sardine and anchovy stocks-the regime problem. South African Journal of Marine Science, 8, pp. 195-205.

[37] McKoy, J., Bagley, N., Gauthier, S., and Devine, J., 2009, Fish Resources of the Arabian Sea coast of Oman: Project summary. In Technical Report 1. Bruce Shallard and Associates. Muscat.

[38] Nair, R., 1958, The sardines. In:"Fisheries of the west coast of India”. S. Jones (Ed.), Central Marine Fisheries Research Station. Mandapam, pp. 3137.

[39] O'Donoghue, S. H., Drapeau, L., Dudley, S.F.J., and Peddemors, V. M., 2010, The KwaZulu-Natal sardine run: shoal distribution in relation to nearshore 
environmental conditions, 1997-2007. African Journal of Marine Science, 32, pp. 293-307.

[40] Peck, M. A., Reglero, P., Takahashi, M., and Catalan, I. A., 2013, Life cycle ecophysiology of small pelagic fish and climate-driven changes in populations. Progress in Oceanography, 116, pp. 220-245.

[41] Piontkovski, S.A., and Banse, K., 2006, Overview of results. In: "The mesoscale structure of the epipelagic ecosystem of the open northern Arabian Sea”. K.Banse and S.A.Piontkovski (Eds.), Universities Press, Hyderabad, pp. $1-9$.

[42] Piontkovski, S.A., Al-Oufi, H.S., and Al-Jufaili, S., 2014, Seasonal and interannual changes of sardine landings in the Sea of Oman. Marine Fisheries Review, 76, 3, pp. 50-59.

[43] Piontkovski, S.A, and Chiffings, T., 2014, Long-term changes of temperature in the Sea of Oman and the western Arabian Sea. International Journal of Oceans and Oceanography, 8, pp. 53-72.

[44] Piontkovski, S.A., Al-Tarshi, M.H., Al-Ismaili, S.M., Al-Jardani, S.S.H., and Al-Alawi, Y.H.A., 2019, Monitoring mesoscale eddies in the western Arabian Sea. International Journal of Oceans and Oceanography, 13, pp. 1-23.

[45] Prasad, R. P., 1953, Swarming of Noctiluca in the Palk Bay and its effect on the "Choodai" fishery with a note on the possible use of Noctiluca as an indicator species. Proceedings of Indian Academy of Sciences, 38, pp. 40-47.

[46] Qasim, S.Z., 1977, Biological productivity of the Indian Ocean. Indian Journal of Marine Sciences, 6, pp. 122-137.

[47] Remya, R., Vivekanandan, E., Manjusha, U., and Nair, P. G., 2013, Seasonal variations in the diet of the Indian oil sardine, Sardinella longiceps Valenciennes off Cochin, Kerala. Indian Journal of Fisheries, 60, pp. 55-59.

[48] Saji, N.H., Goswami, B.N., Vinayachandran, P.N., and Yamagata, T., 1999, A dipole mode in the tropical Indian Ocean. Nature, 401, pp. 360-363.

[49] Sajna, V.H., Zacharia, P.U., Liya, V.B., Rojith, G., Somy, K., Joseph, D., and Grinson, G., 2019, Effect of climatic variability on the fishery of indian oil sardine along Kerala coast. Journal of Coastal Research, S1, 86, pp. 184-192.

[50] Schwartzlose, R. A., Alheit, J., Bakun, A., Baumgartner, T. R., Cloete, R., Crawford,

R. J. M., Fletcher, W.J., Green-Ruiz, Y., Hangen, E., Kawasaki, T., LluchBelka, D., Lluch-Cota, S.E., MacCall, A.D., Matsuura, Y., Nevárez-Martínez, M.O., Parrish, R.H., Roy, C., Serra, R., Shust, K.V., Ward, M.N., and Zuzunaga, J.Z., 1999, Worldwide large-scale fluctuations of sardine and anchovy populations. South African Journal of Marine Science, 21, pp. 289347.

[51] Sekharan, K. V., 1966, On the food of the sardines, Sardinella albella (VAL.) and S. gibbosa (BLEEK.) of the Mandapam area. Indian Journal of Fisheries, 13, pp. 96-141. 
[52] Shinoda, T., Alexander, M.A., and Hendon, H.H., 2004, Remote response of the Indian Ocean to interannual SST variations in the tropical Pacific. Journal of Climate, 17, pp. 362-371.

[53] Sugimoto, T., and Tameishi, H., 1992, Warm-core rings, streamers and their role on the fishing ground formation around Japan. Deep-Sea Research, Part A, 39, pp. S183-S201.

[54] Tameishi, H., Naramura, Y., and Shinomiya, H., 1994, Role of warm streamers in the northward migration of Japanese sardine (Sardinops melanostictus) off Sanriku (Japan). Bulletin of the Japanese Society of Scientific Fisheries, 60, pp. 45-50.

[55] Tang, D.L., Kawamura, H., and Luis, A.J., 2002, Short-term variability of phytoplankton blooms associated with a cold eddy in the northwestern Arabian Sea. Remote Sensing of Environment, 81, pp. 81-89.

[56] Vivekanandan, E., Rajagopalan, M., and Pillai, N.G.K., 2009, Recent trends in sea surface temperature and its impact on oil sardine.In: "Global Climate Change and Indian Agriculture". Indian Council of Agricultural Research, New Delhi, pp. 89-92.

[57] Wada, T., and Kashiwai, M., 1991, Changes in growth and feeding ground of Japanese sardine with fluctuation in stock abundance. In: "Long-term variability of pelagic fish populations and their environment", K. Kawasaki, et al. (Eds.), Pergamon Press, N.Y., pp. 181-190. 
